\title{
Torsion Testicular Patient Characteristics
}

\author{
Safendra Siregar, Devlin Alfiana, Jason Liarto, Zola Wijayanti \\ Department of of Urology, Faculty of Medicine Universitas Padjadjaran \\ Dr. Hasan Sadikin General Hospital Bandung, Indonesia
}

\begin{abstract}
Testicular torsion is an emergency urological condition that is caused by the torsion of the spermatic cord structures, causing disruption of circulation of the affected testicle. This study aimed to describe the characteristics of patients with testicular torsion treated at Dr. Hasan Sadikin General Hospital Bandung from January 2016 to January 2020. This was a retrospective descriptive study on 34 medical records of patients diagnosed and treated for testicular torsion. Nine of 34 patients were $<20$ years old and 25 of 34 patients were $>21$ years old. The onset was mostly between 6 to 24 hours, followed by between 2-7 days, less than 6 hours, between 1-2 weeks, and between 2-4 weeks. Left testicular torsion were more frequent than the right torsion. The etiology of the torsion was mostly idiopathic with no identifiable precedent. Orchidectomy was more frequently performed compared to orchiopexy All but one patient presented with testicular pain as the main symptom. Patients presented mostly with a high risk TWIST score; however, more presented with low risk compared to the intermediate risk TWIST score. Orchidectomy is the most frequently performed operation on pre-pubertal and adult patients, possibly due to relatively delayed presentation ( $>24$ hours) to the hospital to receive treatment. Patients were mostly younger; predominantly with high TWIST score and affected left testicle.
\end{abstract}

Keywords: Orchidectomy, orchidopexy, testicular torsion

\section{Karakteristik Pasien Torsio Testis}

\begin{abstract}
Abstrak
Torsio testis adalah kondisi urologi darurat yang disebabkan oleh puntiran pada struktur korda spermatika dan menyebabkan gangguan suplai. Penelitian ini bertujuan mengetahui karakteristik torsio testis di RSUP Dr. Hasan Sadikin Bandung pada periode Januari 2016-Januari 2020. Penelitian merupakan studi retrospektif deskriptif yang mengambil 34 catatan medis pasien torsio testis. Sembilan dari 34 pasien berusia $\leq 20$ tahun dan 25 dari 34 pasien berusia $>21$ tahun. Sebagian besar gejala muncul dalam 6-24 jam sebagian lainnya muncul setelah 2-4 minggu lalu. Torsio testis lebih sering ditemukan pada testis kiri dibanding dengan kanan. Etiologi terbanyak yaitu idiopatik. Orkidektomi lebih sering dilakukan dibandingkan orkidopeksi. Semua pasien, kecuali satu, mengeluhkan nyeri pada skrotum. Skor TWIST tinggi ditemukan pada sebagian besar pasien; pasien dengan skor TWIST rendah lebih banyak dibandingkan sedang. Orkidektomi merupakan operasi yang paling sering dilakukan, terkait dengan sebagian besar pasien datang setelah terjadinya torsio dalam waktu yang cukup lama ( $>24$ jam). Pasien pada penelitian ini umumnya berusia lebih muda, memiliki skor TWIST yang tinggi, dan torsio ditemukan pada testis kiri.
\end{abstract}

Kata kunci: Orkidektomi, orkidopeksi, torsio testis

Corresponding Author: Devlin Alfiana, Department of of Urology, Faculty of Medicine Universitas Padjadjaran/Dr. Hasan Sadikin General Hospital Bandung, Jalan Pasteur No. 38 Bandung, West Java, Indonesia, Email: devlinalfiana@yahoo.com 


\section{Introduction}

Testicular torsion is an emergency urological condition caused by torsion of the spermatic cord, causing interruption of ipsilateral testicular blood flow. Necrosis of the ipsilateral testicle may occur if treatment is delayed, resulting in infertility due to the testicular damage. As such, early diagnosis and treatment of the condition are required for optimum outcomes. The Testicular Workup for Ischemia and Suspected Torsion (TWIST) score is a tool to rapidly evaluate testicular torsion, allowing its rapid diagnosis and subsequent treatment. The TWIST score composed of five clinical findings to screen testicle torsion with a score in each variable: testicular swelling ( 2 points); hard testicle ( 2 points); absent cremasteric reflex (1 point); nausea or vomiting (1 point); and highriding testicle (1 point). Patients are classified into one of three groups based on the sum of TWIST score: Low (0-2 points), Intermediate (3-4 points), and High-Risk (5-7 points). ${ }^{1}$

Due to its acute nature, it is important to diagnose testicular torsion based on clinical examinations. The most prevalent symptom in patients presenting with testicular torsion is testicular pain, while numerous other urological emergencies may also present the same symptom. Thus, other easily examinable characteristics associated with testicular torsion in order to provide an acceptable and rapid diagnostic result are required to optimize the treatment of such conditions. ${ }^{1}$ Previous studies, specific to the population of patients in West Java, are not yet available. Therefore, this study aimed to describe the characteristics of patients with testicular torsion treated at Dr. Hasan Sadikin General Hospital, Bandung, Indonesia during the period of January 2016-January 2020.

\section{Methods}

This was a retrospective descriptive study using data collected from medical records. The target population of the study was patients with testicular torsion diagnosed and treated at Dr. Hasan Sadikin General Hospital, Bandung, Indonesia during the period of January 2016January 2020. The study was conducted after obtaining ethical approval from the Research Ethics Committee of the Faculty of Medicine, Universitas Padjadjaran, with the issuance of the ethical clearance No. 455/UN6.C.6.14/ $\mathrm{KM} / 2020$. Patients who refused treatment in the hospital were excluded from the study. Nonprobability consecutive sampling of the patients was performed with no sample randomization applied to select the subject of this study. The total minimum sample was 30 patients. Data were collected from the medical records of patients with testicular torsion during the period of the study.

Variables collected for the patients were age, history of trauma, onset, blood flow to the testicle, side of the affected testicle, interval to treatment, and direction of torsion. Data collected were analyzed by using SPSS version 20.0. Descriptive statistics were used to present the data in the study.

\section{Results}

During the study period, a total of 34 patients were included and selected. All patients were diagnosed and treated for testicular torsion,

Table 1 Subject Characteristics

\begin{tabular}{|c|c|}
\hline Variables & $\begin{array}{c}\text { Frequency } \\
(n=34)\end{array}$ \\
\hline \multicolumn{2}{|l|}{ Age } \\
\hline$\leq 20$ years & 25 \\
\hline$>21$ years & 9 \\
\hline \multicolumn{2}{|l|}{ Etiology } \\
\hline During activity & 3 \\
\hline History of trauma & 1 \\
\hline Idiopathic & 30 \\
\hline \multicolumn{2}{|l|}{ Onset of symptoms } \\
\hline$<6$ hours & 7 \\
\hline $6-24$ hours & 13 \\
\hline 2-7 days & 8 \\
\hline $1-2$ weeks & 3 \\
\hline $2-4$ weeks & 3 \\
\hline \multicolumn{2}{|l|}{ Affected side } \\
\hline Left & 21 \\
\hline Right & 13 \\
\hline \multicolumn{2}{|l|}{ Management } \\
\hline $\begin{array}{l}\text { Orchidopexy of the affected } \\
\text { testicles }\end{array}$ & 7 \\
\hline $\begin{array}{l}\text { Orchidectomy of the } \\
\text { affected testicles }\end{array}$ & 27 \\
\hline
\end{tabular}


Table 2 TWIST Score and Symptoms

\begin{tabular}{lc}
\hline \multicolumn{1}{c}{ Clinical Variable } & $\begin{array}{c}\text { Frequency } \\
(\mathbf{n = 3 4 )}\end{array}$ \\
\hline Signs and symptoms & \\
Fever & 1 \\
Vomiting & 3 \\
Prehn sign & 2 \\
Angle sign & 15 \\
Absent cremasteric reflex & 30 \\
High-riding testis & 23 \\
Testicular swelling & 24 \\
Testicular pain & 33 \\
Hard testis on palpation & 25 \\
TWIST score & \\
Low risk & 9 \\
Intermediate risk & 3 \\
High risk & 22 \\
\hline
\end{tabular}

consisting of 9 of 34 patients aged $\leq 20$ years old and 25 patients aged $>21$ years old. The onset of the disorder was mostly between 6 to 24 hours, followed by between 2-7 days, less than 6 hours, between 1-2 weeks, and between 2-4 weeks before visiting the hospital. Left testicular torsion was more frequently found compared to the right testicular torsion among these subjects. The etiology of the testicular torsion was mostly idiopathic with no identifiable precedent. Nearly all patients required orchidectomy during presentation to the hospital, with only 7 out of 34 patients were eligible for testis-sparing surgery.

All but one patient presented with testicular pain as the main symptom. Absent cremasteric reflex, testicular swelling, and hard testis on palpation were identified in almost all patients. Angle sign was found in more than half of the patients. Conversely, the Phren sign was found in only 2 patients. Fever was found only in 1 patient and 3 patients experienced vomiting. The majority of the patients presented with a high risk TWIST score; however, higher proportion of patients presented with a low risk TWIST score compared to the intermediate risk TWIST score.

\section{Discussion}

Acute scrotal pain is one of the commonly encountered complaints presented by patients admitted to the emergency department, particularly among all urological emergencies. Worldwide estimated incidence of testicular torsion indicates that it occurs on younger males, with one in 4,000 males younger than 25 years were diagnosed and subsequently treated for testicular torsion annually. Orchidectomy was performed on $42 \%$ patients diagnosed with testicular torsion. Testicular torsion resulting in anemia of the testicle may cause necrosis, which subsequently affects the decision to salvage or to remove the tissue. ${ }^{2}$

Testicular torsion is a urological emergency. While it may occur on all ages, the peak incidence of the condition was found among adolescence between 12-16 years of age. The classic presentation of testicular torsion is acute and severe scrotal pain at rest. Due to the ongoing necrosis of the testicle from the interruption of blood flow, timely diagnosis and treatment are the most important aspect in order to preserve the fertility of the patient with testicular torsion. Onset of symptoms and reduction of torsion and degree of twisting of the cord are important prognostic factors associated with favorable outcomes in regards to preserving the fertility of the individual. ${ }^{3}$ Testicular salvage in the first six hours is $90-100 \%$, which will then decline in six to 12 hours survival to 20$50 \%$, and $11 \%$ in beyond 12 hours survival. ${ }^{4} \mathrm{~A}$ higher TWIST risk score correlates with higher accuracy for testicular torsion; a score of 7 had $100 \%$ specificity (95\%: CI $98-100 \%)$ and $100 \%$ positive predictive value $(95 \% \mathrm{CI}: 40-$ $100 \%{ }^{5}$ Testicular torsion in Dr. Hasan Sadikin General Hospital, Bandung, Indonesia are more commonly seen in individuals younger than 20 years old.

Bilateral testicular torsion is exceedingly rare; only $2 \%$ of the testicular torsion cases are bilateral. The left side is more commonly affected and, though unknown, it has been hypothesized that left testicle has a longer spermatic cord when compared to the right testicle that it is predisposed to an increased risk of testicular torsion. Testicular torsion occurs more frequently in younger age groups and patients with previous history of cryptorchidism have 10 times higher risk for developing testicular torsion. Lack of pain relief after testicular elevation (Prehn's sign) and absent cremasteric reflex are highly sensitive and specific. There are several instances of intermittent testicular torsion with the case resolves itself after a few hours. The clinical examination during presentation may be normal but further imaging 
studies may discover segmental infarcts due to repeated torsion on a longer period of time. Nausea and vomiting, while not specific, are among the most commonly encountered symptoms in patients with testicular torsion. ${ }^{7}$ Clinical characteristics in this study were similar to the previously reported studies, except in the number of patients presenting with vomiting as the chief complaint. Vomiting was found only in 3 of the total 34 patients included in the study. Delayed presentation of testicular torsion may present as chronic intermittent testicular torsion while the "classical signs" of testicular torsion were similar to the previous studies. The number of the patient presenting with vomiting or fever as systemic complaints may subside due to the non-viable testis. Further studies on this aspect may be required to ascertain the exact pathophysiological mechanisms involved in the evolution of signs and symptoms, particularly in patients receiving delayed treatment.

Delayed diagnosis and treatment were independently associated with poorer prognosis andhigherchancetobeineligiblefortestis-sparing surgery (i.e., orchidopexy). A previous study by Bayne et al. has reported that several symptoms are associated with delayed presentation and misdiagnosis of testicular torsion. This casecontrol study that was performed in the United States has reported that initial abdominal pain without scrotal pain $(p<0.0001)$ are significantly higher in groups with delayed presentation compared to groups with acute presentation. Recent history of genital trauma and previous history of developmental, cognitive, or social disorder $(p<0.05)$ are associated with delayed presentation of testicular torsion in the same study. ${ }^{8}$ Late presentation to the hospital is one of the independent risk factors in worse prognosis, requiring more radical surgeries to treat the condition. Occurrence of scrotal pain in intervals may be associated with lower detection of testicular torsion, particularly in children. ${ }^{9}$

Despite the "classical signs" of testicular torsion being scrotal pain and/or swelling and/ or hardness of affected testicles score higher in the previous TWIST scoring used to determine the risk of testicular torsion, a recent study by Lim et al. has noted that nausea and vomiting has a stronger predictive value compared to scrotal pain. The possible explanation of the variation of symptoms during presentation may be caused by twisting and untwisting of the testes during examination. As such, torsion may be missed due to the intermittent untwisting of the affected testicle during examination. ${ }^{10} \mathrm{~A}$ plausible explanation of the late presentation of the cases may stem from the difficulties in explaining the scrotal pain, particularly in children. Delayed presentation, as mentioned previously, is associated with worse outcomes and lowers the chance of opting for testis-sparing surgery. Virtually all cases that have presented for more than 24 hours after the onset of the testicular torsion result in non-viable testis on the affected side. ${ }^{11}$ Testicular torsion occurs on a higher proportion among younger individuals compared to older individuals. Nearly $38.2 \%$ of all patients are presented to the emergency room within 6-24 hours. Delayed treatment-seeking are also found in numerous cases, extending more than a week.

The study is one of the few studies to explore the characteristics of the patients presenting with testicular torsion. Patients presented in this study tend to delay treatment-seeking for acute scrotal pain. Hence, further studies regarding prospective outcomes of these patients after being treated with orchidopexy and/or orchidectomy after a longer time period may be required.

Testicular torsion is a relatively rare clinical condition where worse prognosis may be associated with delays in treatment. Orchidopexy is the most frequent surgery performed on prepubertal and adult patients. Patients with testicular torsion in Dr. Hasan Sadikin General Hospital, Bandung, Indonesia are mostly younger patients; predominantly with a high TWIST score and affected the left testicle. High frequency of non-sparing testicular surgery (orchidectomy) may be associated with the late presentation of the patients. Therefore, early diagnosis based on clinical measures is required for early treatment in order to improve outcomes and improve the chance of undergoing testis-sparing surgery.

\section{References}

1. Manohar CS, Gupta A, Keshavamurthy R, Shivalingaiah M, Sharanbasappa BR, Singh VK. Evaluation of testicular workup for ischemia and suspected torsion score in patients presenting with acute scrotum. Urol Ann. 2018;10(1):20-3.

2. Sheth KR, Keays M, Grimsby GM, Granberg CF, Menon VS, DaJusta DG, et al. Diagnosing testicular torsion before urological consultation and imaging: validation of the TWIST Score. J Urol. 2016;195(6):1870-6.

3. Hyun GS. Testicular torsion. Rev Urol. 
2018;20(2):104-6.

4. Thomas SZ, Diaz VI, Rosario J, Kanyadan V, Ganti L. Emergency Department approach to testicular torsion: two illustrative cases. Cureus. 2019;11(10):e5967.

5. Frohlich LC, Paydar-Darian N, Cilento BG Jr, Lee LK. Prospective validation of clinical score for males presenting with an acute scrotum. Acad Emerg Med. 2017;24(12):1474-82.

6. Kapoor S. Testicular torsion: a race against time. International Journal of Clinical Practice. 2008;62(5):821-7.

7. Lavallee ME, Cash J. Testicular torsion: evaluation and management. Curr Sports Med Rep. 2005;4(2):102-4.

8. Bayne CE, Villanueva J, Davis TD, Pohl HG,
Rushton HG. Factors associated with delayed presentation and misdiagnosis of testicular torsion: a case-control study. J Pediatr. 2017;186:200-4.

9. Rampaul MS, Hosking SW. Testicular torsion: most delay occurs outside hospital. Ann R Coll Surg Engl. 1998;80(3):169-72.

10. Lim X, Angus MI, Panchalingam V, Chng KI, Choo CS, Chen Y, et al. Revisiting testicular torsion scores in an Asian healthcare system. J Pediatr Urol. 2020;16(6):821.e1-821.e7.

11. Abshari F, Wahyudi I, Rodjani A. Testicular torsion: causative factor in delayed management. Indonesian Journal of Urology. 2018;25(1):19-22. 